\title{
Short communication: J-5 Escherichia coli vaccination does not influence severity of an Escherichia coli intramammary challenge in primiparous cows
}

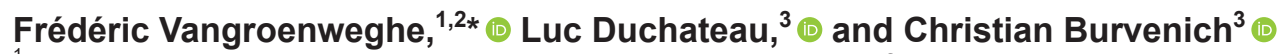 \\ ${ }^{1}$ Elanco Animal Health, BU Food Animals, Plantijn en Moretuslei 1, 3rd floor, 2018 Antwerpen, Belgium \\ ${ }^{2}$ Faculty of Veterinary Medicine, Department of Reproduction, Obstetrics and Herd Health, Ghent University, Salisburylaan 133,9820 Merelbeke, \\ Belgium \\ ${ }^{3}$ Faculty of Veterinary Medicine, Department of Nutrition, Genetics and Ethology, Ghent University, Salisburylaan 133, 9820 Merelbeke, Belgium
}

\begin{abstract}
The objective of the present study was to evaluate the efficacy of a J-5 Escherichia coli vaccine in a mild to moderate inflammatory challenge model using primiparous dairy cows for inoculation only. We hypothesized a clinical difference between placebo and J-5 E. coli vaccinated animals with the mild to moderate inflammatory challenge model. In case the null hypothesis could not be confirmed, the alternate hypothesis was no clinical difference between both treatment groups. Therefore, 23 primiparous cows in mo 7 of pregnancy were randomly assigned to 1 of 2 treatment groups: J-5 $E$. coli vaccine $(\mathrm{n}=12)$ or placebo $(\mathrm{n}=11)$. Animals were vaccinated 3 times at $56( \pm 7)$ and $28( \pm 7)$ d before expected calving date and within $14 \mathrm{~d}$ postcalving (DIM $5 \pm 3$ ). All cows were challenged by infusion with E. coli $\mathrm{P} 4: \mathrm{O} 32$ into 2 left mammary quarters between 14 and $28 \mathrm{~d}$ postparturition, at least $10 \mathrm{~d}$ after the $3 \mathrm{rd}$ vaccination, immediately after the morning milking. Clinical observations and blood and milk samples were collected at several time points from $7 \mathrm{~d}$ pre-challenge until $13 \mathrm{~d}$ post-challenge. Primiparous cows responded mild to moderately to intramammary $E$. coli challenge with little clinical difference between treatment groups. Rectal temperature increased earlier in the vaccinated animals, which also eliminated bacteria faster during the early hours after intramammary $E$. coli challenge. At post-infusion hour 9, the bacterial population was significantly lower in the infected quarters of the vaccinated animals. Blood leukocyte number was only numerically higher in the vaccinated animals, in combination with a numerically higher percentage of late immature polymorphonuclear leukocytes (band cells) in circulation. Even in the nonvaccinated animals, the $E$. coli challenge in the primiparous cows elicited only a mild to moderate response. The absence of a
\end{abstract}

Received October 27, 2019.

Accepted February 10, 2020.

*Corresponding author: vangroenweghe.frederic@telenet.be pronounced clinical difference between vaccinated and nonvaccinated animals was therefore not surprising. Key words: J-5 vaccine, primiparous cow, Escherichia coli mastitis, periparturient period

\section{Short Communication}

It is estimated that up to $10 \%$ of all cases of clinical mastitis in dairy herds during early lactation are caused by coliform bacteria, in particular Escherichia coli, Enterobacter aerogenes, Klebsiella pneumoniae, and Klebsiella oxytoca (Jain, 1979; Smith et al., 1985; De Vliegher et al., 2012), especially in herds where contagious pathogens are well controlled (Schukken et al., 1989a,b; Barkema et al., 1999). Since most of these organisms are either normal gut inhabitants (Smith et al., 1985) or are found in bedding materials (Oz et al., 1985), animals are constantly exposed to these environmental bacteria (Jackson and Bramley, 1983; Gomes and Henriques, 2016). The clinical manifestation of coliform mastitis is often mild, but may sometimes be acute to peracute with occurrence of high fever and toxemia (Hill, 1981). Lipopolysaccharide, an endotoxin derived from E. coli, may cause release of pre-formed inflammatory compounds, resulting in a mediator shock (Hoeben et al., 2000; Dosogne et al., 2002), which may sometimes progress to fatal disease. Treatment of acute and peracute clinical coliform mastitis is quite costly to the dairy farmer and does not always lead to resolution. Pre-parturient cows with a negative energy balance during early lactation are particularly susceptible to coliform mastitis, due to a decrease in the effectiveness of their nonspecific resistance mechanisms at the mammary gland resident milk cell level (Dosogne et al., 2001). Therefore, disease prevention is considered the best option and may consist of decreasing exposure of the teat end to coliforms from the environment (Smith et al., 1985; Schukken et al., 1989a,b) and increasing the animal's resistance to infection.

Vaccination is a viable prevention option. In humans, it has been demonstrated that bacterins produced by 
an E. coli J-5 mutant strain prevented lethal bacteremia due to gram-negative infection (Ziegler et al., $1973,1982)$. The severity of the inflammation and the occurrence of clinical coliform mastitis under field conditions following an IMI with E. coli may be reduced by the use of J-5 E. coli bacterins (González et al., 1989). In other studies (Wilson et al., 2007a); however, J-5 vaccination did not reduce the incidence of coliform mastitis, although protection against severe cases of coliform mastitis resulting in less culling and death losses was observed. An alternative off-label J-5 vaccination scheme evaluated in a novel $E$. coli challenge model could not prevent new IMI either, but also reduced clinical severity of experimentally induced $E$. coli mastitis (Gurjar et al., 2013). Vaccination using the mutant J-5 strain should result in the development of cross-reactive antibodies, able to enhance cow's immunity to gram-negative pathogens that cause coliform mastitis (Tomita et al., 2000; Wilson et al., 2007b). Immunization of lactating cows in peak lactation with 2 different J-5 bacterins did not reduce clinical signs of mastitis (Steele et al., 2019). Recently, it has been shown that primiparous dairy cows are resistant to severe clinical E. coli mastitis (Vangroenweghe et al., 2004a,b), as compared with previous studies with the same challenge model and strain in multiparous cows (Vandeputte-Van Messom et al., 1993), resulting in a mild to moderate inflammatory reaction with complete resolution (Vangroenweghe et al., 2004a,b).

The objective of the present study was to evaluate whether immunization with a bacterin extracted from a J-5 mutant E. coli strain (Enviracor; Zoetis Animal Health, Sandwich, UK) reduces disease severity in primiparous dairy cows challenged intramammarily with $E$. coli. We hypothesized clinical difference between placebo and J-5 E. coli vaccinated animals with the mild to moderate inflammatory challenge model. In case the null hypothesis could not be confirmed, the alternate hypothesis was no clinical difference between both treatment groups.

All primiparous cows $(\mathrm{n}=23)$ were in mo 7 of pregnancy on arrival at a commercial dairy farm and were randomly, based on order of their official ear tag number using an odd/even number system, assigned to 1 of 2 treatment groups: J-5 E. coli vaccine $(\mathrm{n}=12)$ or placebo $(\mathrm{n}=11)$. Animals were vaccinated 3 times at $56( \pm 7)$ and $28( \pm 7)$ d before expected calving date and within $14 \mathrm{~d}$ postcalving (DIM $5 \pm 3$ ). Primiparous cows were inoculated with $10^{6}$ E. coli $\mathrm{P} 4$ :O32 in both left quarters between 14 and 28 d postparturition, at least $10 \mathrm{~d}$ after the third vaccination and immediately after morning milking. Blood and milk samples were collected and quarter milk production was measured at $\mathrm{d}-7,-4,-1,0,+1,+2,+3,+6,+9$, and +13 relative to the day of challenge. Animals were clinically [rectal temperature (RT) and heart rate (HR)] examined and aspects of the mammary gland (abnormal milk, swelling, teat relaxation, and milk leakage) were evaluated at all time points above as previously described (MassartLeën et al., 1988; Vangroenweghe et al., 2004a). On the day of challenge, blood and milk samples were collected at post-infusion hour (PIH) 3, 6, 9, 12, 15, 18, and 21. Different blood [blood leukocyte count (BLC) and differential BLC] and milk [SCC and colony-forming units (cfu) of E. coli] characteristics were assessed as previously described (Vangroenweghe et al., 2004a,b). To compare the 2 treatment groups with respect to the various parameters assessed in blood and milk, a mixed model was used with cow as random effect and treatment, time, and their interaction as categorical fixed effects. Inclusion of the cow random effect induces the compound symmetry correlation structure on the repeated measurements of the cows. Pairwise comparisons were adjusted using Bonferroni's multiple comparisons procedure with an overall type I error equal to 5\%. Quarter milk production in both infected and uninfected quarters was tested for significant differences between treatments at $d+1$ and the interval $d$ +1 to +3 . The effect of treatment on the local aspects of the mammary gland was tested by the Wilcoxon rank sum test.

A significant interaction between time and treatment was only found for RT and cfu. Therefore, only main effects are discussed for all variables but RT and cfu. Following intramammary challenge, RT (Figure 1a) and HR (Figure 1b) increased from PIH 6 onward and reached a peak at PIH 9 in the 2 treatment groups. Rectal temperature and HR rapidly decreased following peak values, and normal values were reached from PIH 18 onwards. The RT did not differ between the 2 treatment groups from 0 to $48 \mathrm{~h}(P=0.43)$, but evolved differently over time in the 2 treatment groups $(P=0.01)$. Rectal temperature was significantly higher at PIH $6(P=0.007)$, but significantly lower at PIH $12(P=0.009)$ in the vaccinated group. No significant differences were found for HR. Following intramammary E. coli inoculation, typical local clinical symptoms occurred at the level of the affected quarters with swelling and abnormal milk (flakes and clots) in the 2 treatment groups. However, during the acute phase of inflammation (PIH 0-48), no significant differences in local swelling and milk appearance were observed between the 2 groups.

Following E. coli challenge, milk production decreased in the infected and uninfected quarters. Milk production rapidly recovered and almost reached pre-infection values in the uninfected quarters after a few days. In the infected quarters, production at $\mathrm{d}+13$ (PIH 312) 

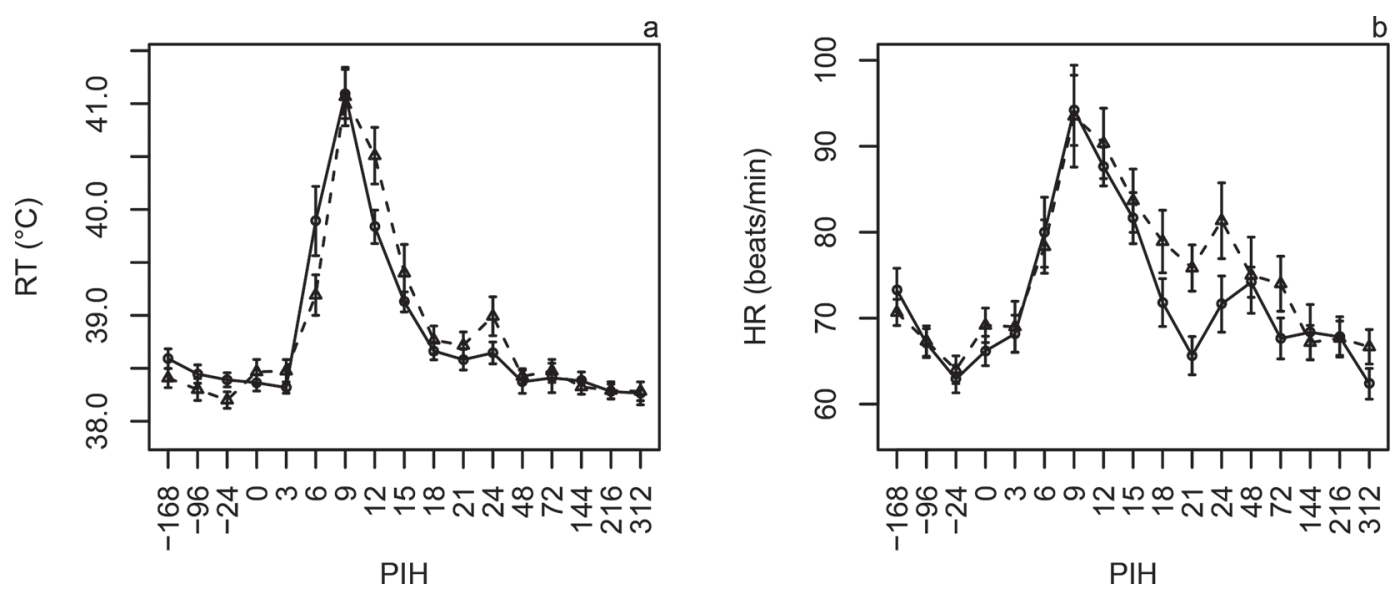

Figure 1. Rectal temperature (RT; a) and heart rate (HR; b) from post-infusion hour (PIH) - 168 until PIH 312 from primiparous cows vaccinated against the endotoxin $(-; \mathrm{n}=12)$ or the placebo $(---; \mathrm{n}=11)$ and intramammarily challenged with $10^{6}$ cfu of Escherichia coli P4:O32. Data are means ( \pm SEM).

was only numerically lower $(-9.8$ and $-11.5 \%$ in the control and J-5 vaccinated group, respectively) than pre-infection $(\mathrm{PIH}-24)$. No significant differences in quarter milk production at $\mathrm{d}+2$, the interval $\mathrm{d}+1$ to +3 , and at $\mathrm{d}+13$ (PIH 312) were observed between the treatment groups in infected and uninfected quarters.

Bacterial growth rapidly reached maximum levels in the 2 treatment groups (Figure 2a). The vaccinated animals eliminated bacteria from the challenged quarters slightly faster during the first hours post-infusion, resulting in a significantly different evolution of cfu over time in the 2 treatment groups $(P=0.0034)$. The number of bacteria $(\mathrm{cfu} / \mathrm{mL}$ ) was significantly lower in the vaccinated group at PIH $9(P=0.006)$. Intramammary $E$. coli challenge resulted in a rapid influx of PMN from the blood into the mammary gland, induc- ing a major increase in SCC in the infected quarters (Figure 2b), but no significant differences between the 2 groups were observed. The highest SCC values occurred at PIH 6, staying at that level for an extended time. Following the acute phase of inflammation, SCC slowly decreased, although at $d+13$, it was still higher than pre-infection.

Following E. coli challenge, BLC rapidly decreased and reached nadir at PIH 9 and 12 in the vaccinated and placebo animals, respectively (Figure 3 ). In the placebo group, BLC remained numerically $(P=0.054)$ lower than in vaccinated animals until PIH 144.

Peak E. coli concentrations in the infected quarters are indicative for the severity of experimental E. coli mastitis (Vandeputte-Van Messom et al., 1993) with typical values of $1 \times 10^{10}, 1 \times 10^{7}$, and $1 \times 10^{4-5} \mathrm{cfu} /$
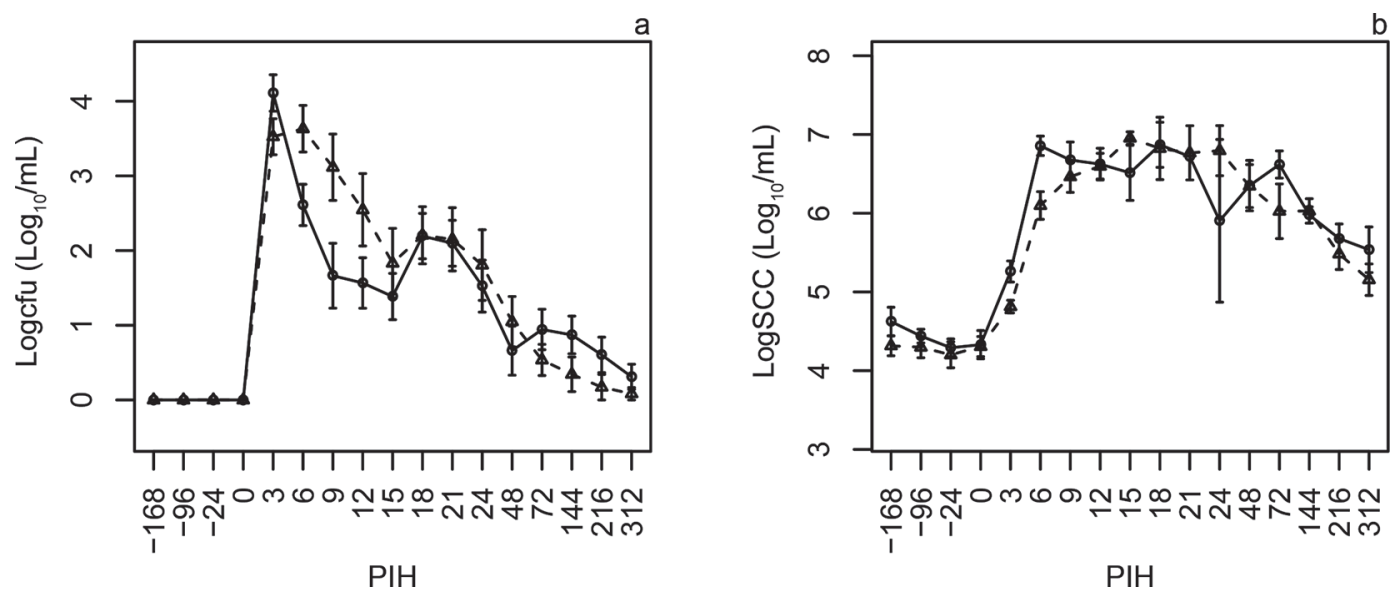

Figure 2. Colony-forming units of Escherichia coli (a) and SCC (b) in the affected quarters from post-infusion hour (PIH) - 168 until PIH 312 from primiparous cows vaccinated against the endotoxin $(-; \mathrm{n}=12)$ or the placebo $(---; \mathrm{n}=11)$ and intramammarily challenged with $10^{6} \mathrm{cfu}$ of $E$. coli $\mathrm{P} 4$ :O32. Data $\left(\log _{10}\right.$-transformed) are means $( \pm \mathrm{SEM})$. 
$\mathrm{mL}$ for severe, moderate, and mild cases, respectively (Shuster et al., 1996; van Werven et al., 1997; Hirvonen et al., 1999; Vangroenweghe et al., 2004a,b). Moreover, mild cases of clinical coliform mastitis have a more rapid elimination of the bacteria from the infected quarters compared with moderate and severe clinical cases. The area under the curve $0-126$ of $\mathrm{cfu} / \mathrm{mL}$ is a significant indicator of severity of clinical E. coli mastitis (Lohuis et al., 1990; Kremer et al., 1993; van Werven et al., 1997). These data, obtained during experimentally induced coliform mastitis, are consistent with field observations by Wenz et al. (2001), who reported a higher proportion of severe cases $(77 \%)$ in the group of animals with E. coli concentrations above $1 \times 10^{5} \mathrm{cfu} / \mathrm{mL}$ compared with moderate $(51 \%)$ and mild $(28 \%)$ cases.

Hogan et al. (1992) compared cows vaccinated with the E. coli J-5 strain with nonvaccinated cows at different levels of $E$. coli challenge and observed that vaccinated cows were faring better with the higher challenge levels. In that study, mean $\log _{10} \mathrm{cfu} / \mathrm{mL}$ in the control group at the time point with the highest value was about $4 \log _{10} \mathrm{cfu} / \mathrm{mL}$ (Hogan et al., 1992). Hence, the cfu challenge obtained in our study should be considered as mild. With the exception of Hogan et al. (1992), most other published challenge studies resulted in peak $\mathrm{cfu} / \mathrm{mL}$ that were lower than $4 \log _{10} \mathrm{cfu} / \mathrm{mL}$. Few modulatory effects on the course of inflammation were present in these studies following vaccination against

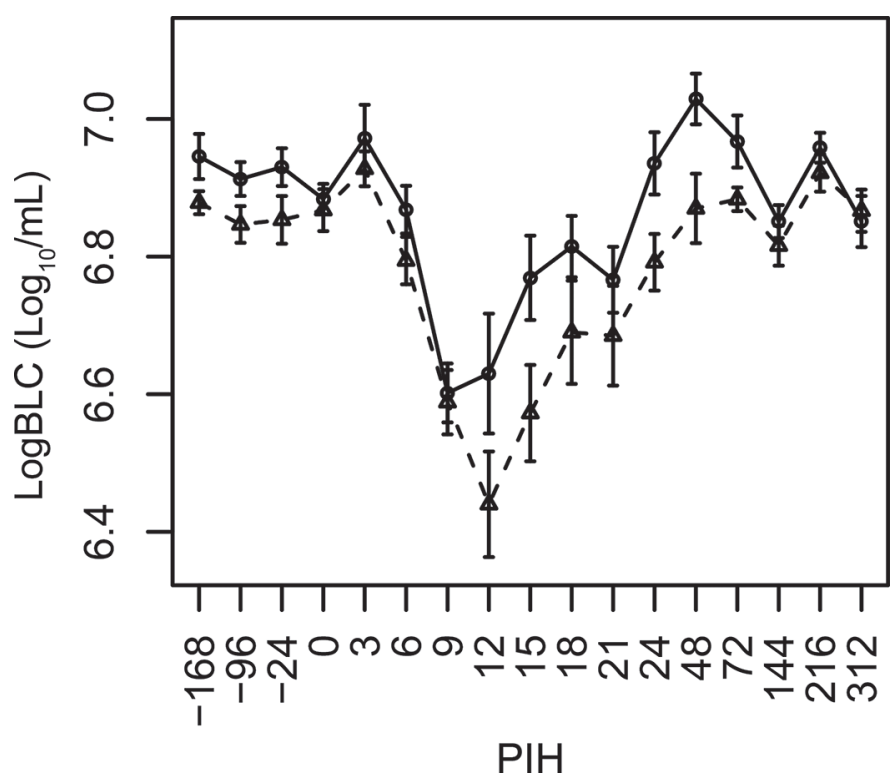

Figure 3. Blood leukocyte count (BLC) in the blood from postinfusion hour (PIH) -168 until PIH 312 from primiparous cows vaccinated against the endotoxin $(-; \mathrm{n}=12)$ or the placebo $(--; \mathrm{n}=$ 11) and intramammarily challenged with $10^{6}$ cfu of Escherichia coli P4: O32. Data ( $\log _{10}$-transformed) are means ( \pm SEM). the endotoxin (Smith et al., 1999), which was also the case in our study.

Severe responders peak at higher RT and HR values (Heyneman et al., 1990; Vandeputte-Van Messom et al., 1993; Shuster et al., 1996; Ohtsuka et al., 2001). Furthermore, moderate responders have fast RT normalization at around PIH 18 (Vangroenweghe et al., 2004a,b). Rectal temperature and HR correlate significantly positive to both $E$. coli $\mathrm{cfu} / \mathrm{mL}$ (Kremer et al., 1993) and milk production in the infected and uninfected quarters (Lohuis et al., 1990). Hence, it is not surprising that, based on the results of quarter milk production and cfu, no significant differences in HR were observed between the vaccinated group and the placebo animals.

Moderate responders are characterized by a rapid and efficient increase in SCC (Vangroenweghe et al., 2004a,b). None of the previously reported experimental challenges comparing cows vaccinated with the $E$. coli J-5 strain with a placebo group observed a significant difference in SCC between treatment groups (Hogan et al., 1992, 1999; Smith et al., 1999), which is in parallel with our study. Following E. coli mastitis challenge, blood leukocyte number first decrease and subsequently increase (van Werven et al., 1997; Ohtsuka et al., 2001). Both the initial decrease and the subsequent increase are larger in severe than in moderate responders (Heyneman et al., 1990; Ohtsuka et al., 2001). This typical pattern of blood leukocyte changes also occurs with endotoxin challenge (Morris et al., 1986). Similar BLC kinetics are observed in the study reported here.

The presently used E. coli mastitis challenge model results consistently in clinical mastitis and has therefore been used frequently to study risk factors influencing the severity of the response to challenge (Heyneman et al., 1990; Kremer et al., 1993; Vandeputte-Van Messom et al., 1993; Dosogne et al., 1997; van Werven et al., 1997; Hoeben et al., 2000; Dosogne et al., 2002). However, it has often been difficult to produce a severe response in this challenge model, especially when the challenge is done outside the periparturient period. A major limitation to obtain a severe clinical response is the fact that in most of the cited J-5 vaccine studies the challenge did not take place within days after calving, the period when animals are most likely to develop severe coliform mastitis (Dosogne et al., 1998). Moreover, recent research has shown that intramammary E. coli infection during late gestation induces predominantly an antiinflammatory immunological response, which may lead to infection persistency in the dry period. This might result in a delayed occurrence of clinical signs to the period immediately after parturition (Quesnell et al., 2012). The variation in severity may also be explained 
by difference in the inoculation strain among studies and with coliform infections observed under field conditions. However, the currently used E. coli strain has induced severe cases of coliform mastitis in previous studies (Vandeputte-Van Messom et al., 1993; Dosogne et al., 1997; Hoeben et al., 2000). Parity and level of negative energy balance, besides interval to parturition, are considered important risk factors for the severity of coliform mastitis (Burvenich et al., 2003). It is known that primiparous cows, as used in the present study, are less susceptible to severe coliform mastitis as compared with older animals (van Werven et al., 1997; Vangroenweghe et al., 2004a,b).

In the present experimental study executed on primiparous cows, pre-calving J-5 vaccination had only limited effects on the clinical systemic severity outcome of experimentally induced E. coli mastitis. The RT and cfu were only slightly affected. It is known that (1) systemic clinical (septic/toxic) systems and susceptibility sepsis during E. coli mastitis are partly related to endotoxin release and (2) endotoxin detoxification is related to efficient neutrophil function. It may therefore be concluded from this study that in primiparous cows an efficient local inflammatory reaction is initiated upon infection, characterized by a rapid and efficient influx of PMN with subsequent local or systemic detoxification (or both) of endotoxins and related toxic agents. This leads to a fast resolution and re-establishment of mammary gland function. J-5 E. coli vaccination can therefore not add much to an already efficient immune system. Multiparous cows are more susceptible to severe E. coli mastitis, and J-5 E. coli vaccination could thus be more effective in multiparous cows. It is clear that though this conclusion sounds logical, it is currently of limited value because it only accounts for this specific experimental study with a limited number of challenged primiparous cows. Therefore, we would recommend testing the $\mathrm{J}-5$ vaccine in field trials on a larger number of cows, where the J-5 E. coli vaccination effect on primiparous and multiparous cows can be distinguished.

\section{ACKNOWLEDGMENTS}

This study was supported by the Flemish Agency for Innovation and Entrepreneurship (VLAIO - grant no. 030784). The authors acknowledge H. De Luycker and Pfizer/Zoetis Animal Health for providing the J-5 E. coli vaccine (Enviracor. The authors greatly appreciated the excellent technical assistance of E. Vander Elstraeten, A. Vervloet, E. Van Driessche, J. Van Groenweghe, G. Corneillie, K. Demeyere, and J.-P. Fontaine (Ghent University, Faculty of Veterinary Medicine,
Department of Nutrition, Genetics and Ethology). The authors have not stated any conflicts of interest.

\section{REFERENCES}

Barkema, H. W., Y. H. Schukken, T. J. G. M. Lam, M. L. Beiboer, G. Benedictus, and A. Brand. 1999. Management practices associated with the incidence rate of clinical mastitis. J. Dairy Sci. 82:16431654. https://doi.org/10.3168/jds.S0022-0302(99)75393-2.

Burvenich, C., V. Van Merris, J. Mehrzad, A. Diez-Fraile, and L. Duchateau. 2003. Severity of $E$. coli mastitis is mainly determined by cow factors. Vet. Res. 34:521-564. https://doi.org/10.1051/vetres: 2003023.

De Vliegher, S., L. K. Fox, S. Piepers, S. McDougall, and H. W. Barkema. 2012. Invited review: Mastitis in dairy heifers: Nature of the disease, potential impact, prevention and control. J. Dairy Sci. 95:1025-1040. https://doi.org/10.3168/jds.2010-4074.

Dosogne, H., C. Burvenich, T. van Werven, E. Roets, E. N. Noordhuizen-Stassen, and B. Goddeeris. 1997. Increased surface expression of CD11b receptors on polymorphonuclear leukocytes is not sufficient to sustain phagocytosis during Escherichia coli mastitis in early postpartum dairy cows. Vet. Immunol. Immunopathol. 60:47-59. https://doi.org/10.1016/S0165-2427(97)00089-5.

Dosogne, H., A. V. Capuco, M. J. Paape, E. Roets, C. Burvenich, and B. Fenwick. 1998. Reduction of acyloxyacyl hydrolase activity in circulating neutrophils from cows after parturition. J. Dairy Sci. 81:672-677. https://doi.org/10.3168/jds.S0022-0302(98)75622-X.

Dosogne, H., E. Meyer, A. Sturk, J. van Loon, A.-M. Massart-Leën, and C. Burvenich. 2002. Effect of enrofloxacin treatment on plasma endotoxin during bovine Escherichia coli mastitis. Inflamm. Res. 51:201-205. https://doi.org/10.1007/PL00000293.

Dosogne, H., F. Vangroenweghe, B. Barrio, P. Rainard, and C. Burvenich. 2001. Decreased number and bactericidal activity against Staphylococcus aureus of the resident cells in milk of dairy cows during early lactation. J. Dairy Res. 68:539-549. https://doi.org/ $10.1017 /$ S0022029901005088.

Gomes, F., and M. Henriques. 2016. Control of bovine mastitis: Old and recent therapeutic approaches. Curr. Microbiol. 72:377-382. https://doi.org/10.1007/s00284-015-0958-8.

González, R. N., J. S. Cullor, D. E. Jasper, T. B. Farver, R. B. Bushnell, and M. N. Oliver. 1989. Prevention of clinical coliform mastitis in dairy cows by a mutant Escherichia coli vaccine. Can. J. Vet. Res. 53:301-305.

Gurjar, A. A., S. Klaessig, S. A. Salmon, R. J. Yancey Jr., and Y. H. Schukken. 2013. Evaluation of an alternative dosing regimen of a J-5 mastitis vaccine against intramammary Escherichia coli challenge in nonlactating late-gestation dairy cows. J. Dairy Sci. 96:5053-5063. https://doi.org/10.3168/jds.2012-6456.

Heyneman, R., C. Burvenich, and R. Vercauteren. 1990. Interaction between the respiratory burst activity of neutrophil leukocytes and experimentally induced Escherichia coli mastitis cows. J. Dairy Sci. 73:985-994. https://doi.org/10.3168/jds.S0022-0302(90)78756 -5 .

Hill, A. W. 1981. Factors influencing the outcome of Escherichia coli mastitis in the dairy cow. Res. Vet. Sci. 31:107-112. https://doi .org/10.1016/S0034-5288(18)32532-3.

Hirvonen, J., K. Eklund, A. M. Teppo, G. Huszenicza, M. Kulcsar, H. Saloniemi, and S. Pyörälä. 1999. Acute phase response in dairy cows with experimentally induced Escherichia coli mastitis. Acta Vet. Scand. 40:35-46.

Hoeben, D., C. Burvenich, E. Trevisi, G. Bertoni, J. Hamann, R. M. Bruckmaier, and J. W. Blum. 2000. Role of endotoxin and TNF-a in the pathogenesis of experimentally induced coliform mastitis in periparturient cows. J. Dairy Res. 67:503-514. https://doi.org/10 $.1017 /$ S0022029900004489.

Hogan, J. S., V. L. Bogacz, M. Aslam, and K. L. Smith. 1999. Efficacy of an Escherichia coli J5 bacterin administered to primigravid heifers. J. Dairy Sci. 82:939-943. https://doi.org/10.3168/jds.S0022 -0302(99)75312-9. 
Hogan, J. S., W. P. Weiss, D. A. Todhunter, K. L. Smith, and P. S. Schoenberger. 1992. Efficacy of an Escherichia coli J5 mastitis vaccine in an experimental challenge trial. J. Dairy Sci. 75:415-422. https://doi.org/10.3168/jds.S0022-0302(92)77777-7.

Jackson, E., and J. Bramley. 1983. Coliform mastitis. In Pract. 5:135147. https://doi.org/10.1136/inpract.5.4.135.

Jain, N. C. 1979. Common mammary pathogens and factors of infection in mastitis. J. Dairy Sci. 62:128-134. https://doi.org/10.3168/ jds.S0022-0302(79)83214-2.

Kremer, W. D. J., E. N. Noordhuizen-Stassen, F. J. Grommers, Y. H. Schukken, R. Heeringa, A. Brand, and C. Burvenich. 1993. Severity of experimental Escherichia coli mastitis in ketonemic and nonketonemic dairy cows. J. Dairy Sci. 76:3428-3436. https://doi .org/10.3168/jds.S0022-0302(93)77681-X.

Lohuis, J. A. C. M., Y. H. Schukken, J. H. M. Verheijden, A. Brand, and A. S. J. P. A. M. Van Miert. 1990. Effect of severity of systemic signs during the acute phase of experimentally induced Escherichia coli mastitis on milk production losses. J. Dairy Sci. 73:333-341. https://doi.org/10.3168/jds.S0022-0302(90)78678-X.

Massart-Leën, A.-M., G. Vandeputte-Van Messom, and C. Burvenich. 1988. Oxytocin release during experimentally induced fever and inflammation in lactating ruminants. Arch. Int. Physiol. Biochim. 96:43-44.

Morris, D. D., J. S. Cullor, R. H. Whitlock, M. Wickstrom, and L. B. Corbeil. 1986. Endotoxemia in neonatal calves given antiserum to a mutant Escherichia coli (J-5). Am. J. Vet. Res. 47:2554-2565.

Ohtsuka, H., K. Kudo, K. Mori, F. Nagai, A. Hatsugaya, M. Tajima, K. Tamura, F. Hoshi, M. Koiwa, and S. Kawamura. 2001. Acute phase response in naturally occurring coliform mastitis. J. Vet. Med. Sci. 63:675-678. https://doi.org/10.1292/jvms.63.675.

Oz, H. H., R. J. Farnsworth, and V. L. Larson. 1985. Environmental mastitis. Vet. Bull. 55:829-840.

Quesnell, R. R., S. Klaessig, J. L. Watts, and Y. H. Schukken. 2012. Bovine intramammary Escherichia coli challenge infections in late gestation demonstrate a dominant antiinflammatory immunological response. J. Dairy Sci. 95:117-126. https://doi.org/10.3168/ jds.2011-4289.

Schukken, Y. H., F. J. Grommers, D. van de Geer, and A. Brand. 1989a. Incidence of clinical mastitis on farms with low somatic cell counts in bulk milk. Vet. Rec. 125:60-63. https://doi.org/10 $.1136 / v r .125 .3 .60$

Schukken, Y. H., D. van de Geer, F. J. Grommers, J. A. H. Smit, and A. Brand. 1989b. Intramammary infections and risk factors for clinical mastitis in herds with low somatic cell counts in bulk milk. Vet. Rec. 125:393-396. https://doi.org/10.1136/vr.125.15.393.

Shuster, D. E., E. K. Lee, and M. E. Kehrli Jr.. 1996. Bacterial growth, inflammatory cytokine production, and neutrophil recruitment during coliform mastitis in cows within ten days after calving, compared with cows at midlactation. Am. J. Vet. Res. 57:15691575 .

Smith, J. L., J. S. Hogan, and K. L. Smith. 1999. Efficacy of intramammary immunization with an Escherichia coli J5 bacterin. J. Dairy Sci. 82:2582-2588. https://doi.org/10.3168/jds.S0022 -0302(99)75513-X.

Smith, K. L., D. A. Todhunter, and P. S. Schoenberger. 1985. Environmental mastitis: Cause, prevalence, prevention. J. Dairy Sci. 68:1531-1553. https://doi.org/10.3168/jds.S0022-0302(85)80993 $-0$.

Steele, N. M., T. H. Swartz, K. M. Enger, H. Schramm, R. R. Cockrum, S. J. Lacy-Hulbert, R. R. White, J. Hogan, and C. S. Petersson-Wolfe. 2019. The effect of J5 bacterins on clinical, behav- ioral, and antibody response following an Escherichia coli intramammary challenge in dairy cows at peak lactation. J. Dairy Sci. 102:11233-11249. https://doi.org/10.3168/jds.2019-16549.

Tomita, G. M., C. H. Ray, S. C. Nickerson, W. E. Owens, and G. F. Gallo. 2000. A comparison of two commercially available Escherichia coli $\mathrm{J} 5$ vaccines against $E$. coli intramammary challenge. J. Dairy Sci. 83:2276-2281. https://doi.org/10.3168/jds.S0022 $-0302(00) 75112-5$.

van Werven, T., E. N. Noordhuizen-Stassen, A. J. Daemen, Y. H. Schukken, A. Brand, and C. Burvenich. 1997. Pre-infection in vitro chemotaxis, phagocytosis, oxidase burst, and expression of CD11/ CD18 receptors and their predictive capacity on the outcome of mastitis induced in dairy cows with Escherichia coli. J. Dairy Sci. 80:67-74. https://doi.org/10.3168/jds.S0022-0302(97)75913-7.

Vandeputte-Van Messom, G., C. Burvenich, E. Roets, A.-M. MassartLeën, R. Heyneman, W. D. J. Kremer, and A. Brand. 1993. Classification of newly calved cows into moderate and severe responders to experimentally induced Escherichia coli mastitis. J. Dairy Res. 60:19-29. https://doi.org/10.1017/S002202990002731X.

Vangroenweghe, F., L. Duchateau, and C. Burvenich. 2004a. Moderate inflammatory reaction during experimental $E$. coli mastitis in primiparous cows. J. Dairy Sci. 87:886-895. https://doi.org/10.3168/ jds.S0022-0302(04)73233-6.

Vangroenweghe, F., P. Rainard, M. J. Paape, L. Duchateau, and C. Burvenich. 2004b. Increase in Escherichia coli inoculum doses induce faster innate immune response in primiparous cows. J. Dairy Sci. 87:4132-4144. https://doi.org/10.3168/jds.S0022 -0302(04)73556-0.

Wenz, J. R., G. M. Barrington, F. B. Garry, R. P. Dinsmore, and R. J. Callan. 2001. Use of systemic disease signs to assess disease severity in dairy cows with acute coliform mastitis. JAVMA 218:567572. https://doi.org/10.2460/javma.2001.218.567.

Wilson, D. J., Y. T. Grohn, G. J. Bennett, R. N. González, Y. H. Schukken, and J. Spatz. 2007a. Comparison of J5 vaccinates and controls for incidence, etiologic agent, clinical severity, and survival in the herd following naturally occurring cases of clinical mastitis. J. Dairy Sci. 90:4282-4288. https://doi.org/10.3168/jds 2007-0160.

Wilson, D. J., B. A. Mallard, J. L. Burton, Y. H. Schukken, and Y. T. Gröhn. 2007b. Milk and serum J5-specific antibody responses, milk production change, and clinical effects following intramammary Escherichia coli challenge for J5 vaccinate and control cows. Clin. Vaccine Immunol. 14:693-699. https://doi.org/10.1128/CVI .00104-07.

Ziegler, E. J., H. Douglas, J. E. Sherman, C. E. Davis, and A. I. Braude. 1973. Treatment of E. coli and Klebsiella bacteremia in agranulocytic animals with antiserum to a UDP-gal epimerasedeficient mutant. J. Immunol. 111:433-438.

Ziegler, E. J., J. A. McCutchan, J. Fierer, M. P. Glauser, J. C. Sadoff, H. Douglas, and A. I. Braude. 1982. Treatment of gram-negative bacteremia and shock with human antiserum to a mutant Escherichia coli. N. Engl. J. Med. 307:1225-1230. https://doi.org/10 .1056/NEJM198211113072001.

\section{ORCIDS}

Frédéric Vangroenweghe 느 https://orcid.org/0000-0003-0569-9503 Luc Duchateau (1) https://orcid.org/0000-0003-0462-3638 Christian Burvenich @ https://orcid.org/0000-0002-1156-0981 